\title{
BMJ Open Systematic review of the literature on viral persistence and sexual transmission from recovered Ebola survivors: evidence and recommendations
}

\author{
Anna Thorson, ${ }^{1,2}$ Pierre Formenty, ${ }^{1}$ Clare Lofthouse, ${ }^{1}$ Nathalie Broutet ${ }^{1}$
}

To cite: Thorson $A$, Formenty P, Lofthouse C, et al. Systematic review of the literature on viral persistence and sexual transmission from recovered Ebola survivors: evidence and recommendations. BMJ Open 2016:6:e008859. doi:10.1136/bmjopen-2015008859

- Prepublication history and additional material is available. To view please visit the journal (http://dx.doi.org/ 10.1136/bmjopen-2015008859).

Received 21 May 2015 Revised 28 October 2015 Accepted 30 October 2015

\section{(a) CrossMark}

${ }^{1}$ World Health Organization (WHO), Geneva, Switzerland ${ }^{2}$ Department of Public Health Sciences, Karolinska Institutet, Stockholm, Sweden

Correspondence to Professor Anna Thorson; Anna.Thorson@ki.se

\section{ABSTRACT}

Objective: The main aim of this article is to present a comprehensive, systematic review on evidence of sexual transmission from Ebola survivors and persistence of Ebola virus in body fluids of relevance to sexual transmission, and additionally to review condom effectiveness against sexual transmission of Ebola.

Design: We performed a systematic review of viral persistence in body fluids of relevance to sexual transmission of Ebola survivors and evidence of sexual transmission of Ebola, and carried out a targeted review of condom effectiveness.

Results: We identified nine published original articles presenting results on persistence of Ebola virus in relevant body fluids, or reporting suspect sexual transmission from Ebola survivors. We also included unpublished reports from the current 2014/2015 Ebola epidemic in West Africa. We found no articles reporting on condom effectiveness, but have included a targeted review on general condom efficacy and effectiveness.

Conclusions: We conclude that the risk of sexual transmission from people who have recovered from Ebola cannot be ruled out. We found the longest duration of persistent Ebola RNA in a relevant body fluid from a survivor, to be reported from a man in Sierra Leone who had reverse transcriptase PCR (RTPCR) positive semen 284 days after symptom onset. In line with current WHO recommendations. We recommend that men are offered the possibility to test their semen regularly for presence of Ebola RNA from3 months post-symptom onset. Safe sex practices including sexual abstinence, or else condom use, are recommended by WHO until semen has tested negative twice, or in absence of testing for at least 6 months post-symptom onset. Based on evidence reviewed, we conclude that male and female latex condoms offer some protection against EBOV compared to no condom use. Survivors should be offered access to care and prevention, in order to provide them with possibilities to mitigate any risks that may occur, and efforts should be linked to destigmatising activities.

\section{Strengths and limitations of this study}

- We present a unique, current and comprehensive evidence review in relation to Ebola viral persistence in body fluids and sexual transmission for Ebola virus disease (EVD) survivors. We include the recent literature as well as reports from the West African epidemic 2013 to present.

- We have reviewed condom efficacy and effectiveness in relation to Ebola similarly sized sexually transmitted viruses to ascertain protection and risk for survivors.

- We provide evidence to guide recommendations on sexual health and follow-up care for survivors.

- The primary limitation of the review is the scarcity of published and unpublished evidence on viral persistence in the body fluids of survivors over time, including a paucity of thorough investigations into suspect sexual transmission chains.

\section{INTRODUCTION}

The Ebola virus disease (EVD) outbreak that started in West Africa in December 2013 has had enormous damaging consequences to the affected countries, especially Guinea, Liberia and Sierra Leone. As we write, on 27 October 2015, there have been 28512 reported confirmed, probable and suspected cases of EVD in Guinea, Liberia and Sierra Leone, including 11313 reported deaths. ${ }^{1}$ While the initial Ebola response was targeted at slowing transmission amidst the overwhelming needs of weak health systems, the focus has now moved to ending the epidemic by reaching and sustaining zero new cases. An essential part of this goal is to ensure effective case finding, by contact tracing, so that "each and every chain of transmission can be tracked and terminated."

Transmission of Ebola virus happens primarily while in direct contact with acute sick 
patients or with individuals who have died of EVD. Ebola virus can be transmitted through broken skin or mucous membranes from the blood, body fluids and secretions of the infected person, ${ }^{2}{ }^{3}$ while aerosol transmission has not been documented. ${ }^{3}$ Severe or fatal Ebola disease is associated with rapidly increasing and comparably higher viral loads during the acute phase. ${ }^{24}$ Less is known of post-recovery viral persistence of EBOV and the risk of sexual transmission. ${ }^{5-7}$ Sexual transmission remains an unknown risk, yet it has garnered some attention. However, a systematic approach addressing the evidence continues to be lacking. The main aim of this article is to present a comprehensive, systematic review on evidence of sexual transmission from Ebola survivors and persistence of Ebola virus in body fluids of relevance to sexual transmission. An additional objective is to review condom effectiveness against sexual transmission of Ebola, in order to guide future recommendations on the transmission of the Ebola virus.

\section{METHODS}

\section{Search strategies}

Electronic searches were performed in PubMed/ MEDLINE. The searches included medical subject headings $(\mathrm{MeSH})$ and key words for Ebola together with viral persistence, body fluids (including semen and vaginal secretions as well as faeces, saliva, sweat and urine) and sexual transmission. Searches were designed to be broad and comprehensive initially (see online supplementary appendix 1).

The searches were performed from 8 to 10 December 2014. All languages were accepted and no time limit was set. Searches were repeated until final drafting of the manuscript, in order to capture emerging evidence from the ongoing epidemic (see online supplementary appendix 2). Viral persistence in faeces, saliva, sweat and urine were included as sexual acts can involve mucosal contact of one partner with another's body fluids and would be of interest in discussions on possible routes of sexual transmission.

Unpublished reports and non-peer-reviewed sources were scanned by regular attendance at Ebola epidemic update meetings, reading of country reports, and regular internet searches and feeds. A preliminary report of findings of semen positivity and suspect sexual transmission from the ongoing epidemic in Liberia was added, and the matching published paper was later identified in the repeat searches. In addition, one supplementary non-peer-reviewed report of semen positivity from the current epidemic, a survivor diagnosed with viral persistence in India, was included (see online supplementary appendix 2).

\section{Search terms, process and results}

The initial search generated 121 results (see online supplementary appendix 2). Citations were downloaded, organised and reviewed. Titles that indicated in vitro or animal studies were excluded. Second, all abstracts were reviewed, and, if deemed possible to contain information related to the aim, the full article was reviewed. In summary, a total of nine articles were identified as relevant for the review.

The nine articles, and the unpublished and non-peer-reviewed materials included, were scrutinised for information on: epidemic study setting, sexual transmission chains from recovered patients and EBOV persistence in any of the body fluids of interest. Details on the following pieces of information were extracted and tabulated:

- Methods to identify Ebola virus in the sample;

- Results and number of samples provided per recovered patient;

- Timing of sampling in relation to days post-symptom onset of Ebola.

Two papers reported on different aspects of follow-up and analyses of semen in Ebola survivors from the same epidemic setting. The reported data in the two papers refer to study participants with identical patient ID and ages, and the sample was hence considered to be the same. ${ }^{8} 9$ The search and review strategy is further detailed in the PRISMA flow chart (see online supplementary appendix 2).

\section{Laboratory methods to identify Ebola virus in the literature reviewed}

Within the literature examined, the most commonly used methods for detecting Ebola virus in body fluids were virus isolation together with detection of Ebola RNA by reverse transcription PCR (RT-PCR) or the virus antigen by ELISA. Virus isolation requires a cold chain, is time consuming (3-5 weeks) and involves handling of viable virus in a BSL4-level, high-security laboratory. Handling may be challenging in low-income settings. ${ }^{10}$ The RT-PCR detects copies of viral RNA, but does not distinguish between viable, infectious, virus and RNA remains.

\section{Targeted review on condom efficacy and effectiveness}

No publications were found that included studies on condom protection in relation to Ebola virus, instead we performed a targeted review focusing specifically on 'efficacy, effectiveness, safety, leakage, breakage and slippage'. Cochrane reviews and systematic reviews were given preference to original articles. Manufacturing standard procurement documents were also reviewed.

\section{RESULTS}

\section{Evidence of persisting Ebola virus in semen}

Evidence suggestive of persistent Ebola viruses in semen has been found in five different Ebola outbreaks, including the current epidemic.

EBOV (Ebola virus-Zaire) in semen has been isolated from two men, with infections stemming from two earlier epidemic settings, Kikwit, Congo, in 1995, and 
Gabon in 1997. The case from Kikwit had the longest semen positivity described, with a positive virus isolation of EBOV on day 82 post-onset. Follow-up sampling was not performed until day 700 post-onset. $^{8}{ }^{9} 11$

Isolation of SUDV (Ebola virus-Sudan) is reported from a man infected and treated in London, but the infection had stemmed from the Sudanese epidemic in 1976; there was also a report from the epidemic in Gulu, Uganda, in 2000, where one man had a positive semen sample with virus isolation on day 40 after his symptoms started $^{1213}$ (figure 1).

Detection of EBOV RNA by RT-PCR in semen specimens has further been reported from three other men infected during the epidemic in Kikwit, Congo. ${ }^{8} 9$ During the recent EBOV outbreak in 2014-2015, a suspect case of sexual transmission led to the analysis of semen from one man in Liberia. The semen specimen was positive with RT-PCR on day 199. ${ }^{14} 15$ A man travelling from Liberia to New Delhi, India, following his confirmed recovery from acute Ebola in November 2014, was found to still have presence of EBOV RNA in his semen until some 140 days after symptom onset (Formenty P. Personal communication with National Institute of Virology, Pune, India 2015).

The longest measured duration of persisting EBOV in semen is 284 days, reported from a man in Sierra Leone, infected during the current epidemic. ${ }^{16}$ The evidence describing duration of viral persistence in semen is summarised in figure 1.

\section{Evidence of persisting EBOV in vaginal secretions}

Within the outbreak of EBOV in Kikwit, Congo (DRC), in 1995, 20 female convalescent patients provided 44 vaginal swab specimens at different intervals, ranging from days 12 to 57 post-onset of symptoms. ${ }^{8}$ All the samples were negative for virus isolation and for viral antigen detection by ELISA.
Six female convalescent patients provided vaginal swab specimens for additional virus isolation and RT-PCR testing, ranging from days 20 to 33 post-onset of symptoms. ${ }^{8}$ Only one woman had EBOV RNA detected in her vaginal swab specimen, the latest positive test for detection was performed on day 33 following the start of symptoms, and no further follow-up was carried out. Figure 2 displays an overview of the women tested and the results.

Evidence of persisting Ebola virus in faeces, saliva, sweat and urine

Faeces analyses or rectal swabs have been performed in 30 patients across different epidemic situations, and analysed with either detection by RT-PCR or virus isolation. Only one patient had a positive examination for viral RNA in faeces, with positive rectal swabs on days 22 and 29. The same woman was the only one to have a positive RT-PCR in vaginal secretions ${ }^{8}$ (table 1 ).

Analyses of persisting Ebola virus in saliva have been performed on a total of 35 convalescent patients, including RT-PCR analyses in 13 of these cases. Virus was detected neither by RT-PCR nor by virus isolation in the saliva and throat specimens from convalescent

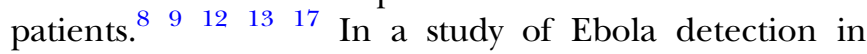
Congo during the outbreaks in 2003, oral fluid samples of acutely sick patients were analysed for both antigen and antibody detection. ${ }^{18}$ While RT-PCR was positive in all specimens from patients with acute Ebola disease, no antigen was detected from the same specimens. The authors conclude that this may be the result of minimal passage of antigen from blood to saliva ${ }^{18}$ (table 1).

Evidence from one male patient, infected in Sierra Leone in 2014 and treated in Germany, shows viable Ebola virus was found in urine until day 26 postsymptom onset, while blood was negative for EBOV from day 18. EBOV RNA was detected by RT-PCR until day 30
Figure 1 Depiction of the duration of measured persistence of Ebola virus and Ebola virus RNA in semen (VI, virus isolation).

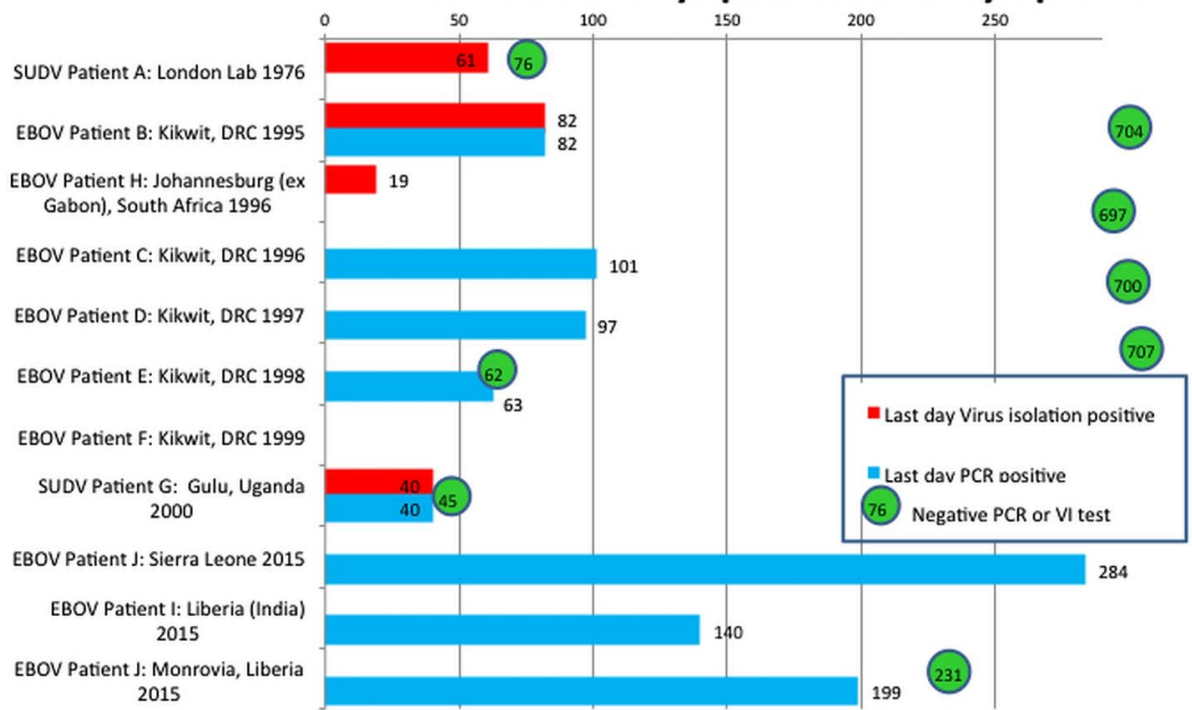




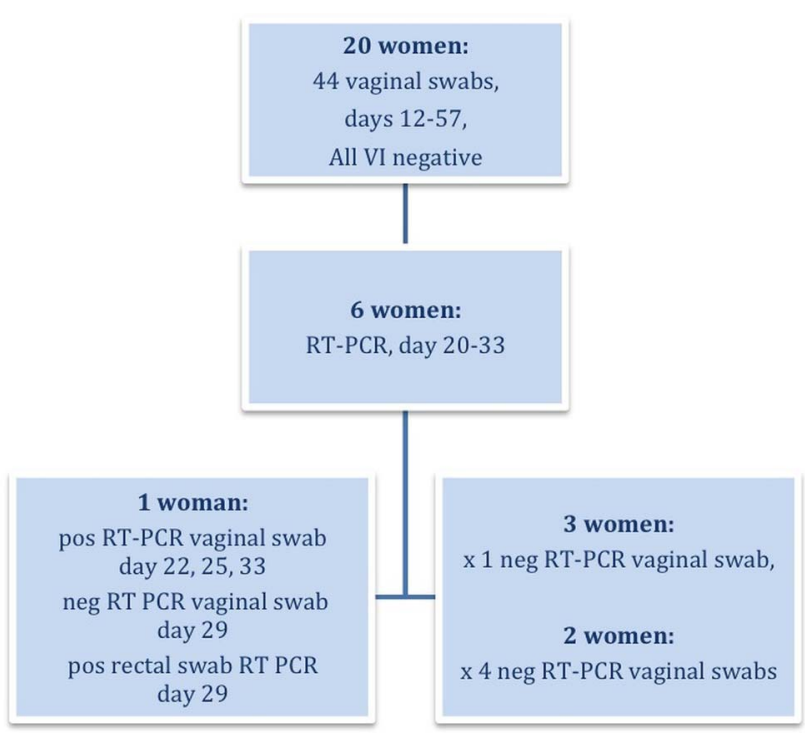

Figure 2 Vaginal swab specimen examined for viral shedding (Days, days post-symptom onset; RT-PCR, reverse transcriptase PCR; VI, virus isolation).

in urine and $>$ day 40 in sweat (no further follow-up yet published), but quantified RNA levels were decreasing with time. Ebola virus was not isolated from his sweat ${ }^{17}$ (table 1).

\section{Evidence of sexual transmission from convalescent patients}

A case of sexual transmission in humans was established for the Marburg virus, in the 1967 epidemic. ${ }^{19}$ In Kikwit, in 1995, of 81 household-contacts followed for some 21 months, one 20-year-old woman had a weakly positive IgM response 52 days after sexual exposure from a convalescent partner. She had a later IgG negative serum sample. The ambiguous antibody results make interpretations, as to whether she may have had an asymptomatic
Ebola infection or not, difficult. ${ }^{9}$ A case-control study from Kikwit additionally showed that household contacts who had had direct physical contact with the acutely ill or with a dead patient, or who were exposed to their body fluids, were at risk of acquiring infection, whereas none of the 78 household members without physical contact with the case during the acute illness got infected. $^{20}$

Molecular evidence suggestive of suspect sexual transmission from an Ebola convalescent has been reported from the current epidemic in Liberia. ${ }^{21} \mathrm{~A}$ male Ebola survivor was discovered to have a positive EBOV RNA in his semen 199 days post-symptom onset when his wife fell ill with acute Ebola, without having a reported exposure to acute EVD. ${ }^{14}$ Matching of genetic sequences strongly suggest that the route of transmission was sexual. $^{14} 21$

Furthermore, a doctor at a clinic in Monrovia, Liberia, reported three cases of suspect sexual transmission from male survivors to their female partners. For one of the female partners surviving her acute Ebola, a concurrent timeline could be established between sexual exposure and symptom onset. She reported no other known exposure to the Ebola virus. ${ }^{22}$ Recent reports from Bombali, Koinadougou and Port Loko districts, in Sierra Leone, similarly suggest suspected sexual transmission from several men to their female partners, while no in-depth investigations have yet been reported. ${ }^{23} 24$

\section{Male and female latex condom efficacy}

Procured male latex condoms are regularly quality controlled against ISO (International Organisation of Standardisation) standards. These include tests for stability, leakage and breakage, to be fulfilled by every manufactured lot and/or individual condom. ${ }^{25} \mathrm{~A}$ female latex condom has been approved by the US Food and Drug Administration (FDA) and the WHO/UNFPA, with manufacturing standards and efficacy that, to a large

Table $1 \mathrm{VI}$ and RT-PCR findings in other body fluids in recovered patients 89121317

\begin{tabular}{|c|c|c|c|c|c|}
\hline & EBOV & Faeces or rectal swabs & Throat swabs or saliva & Sweat & Urine \\
\hline Patient 1, London, 1976 & EBOV & $-\mathrm{VI}$ days $14-27$ & $-\mathrm{VI}$ days $14-27$ & NA & $-\mathrm{VI}$ days $14-27$ \\
\hline $\begin{array}{l}29 \text { Recovered patients, } \\
\text { Kikwit, DRC, } 1995\end{array}$ & EBOV & $-\mathrm{VI}$ days $11-57$ & $-\mathrm{VI}$ days $11-57$ & NA & $-\mathrm{VI}$ days $11-57$ \\
\hline $\begin{array}{l}8 \text { Recovered patients, } \\
\text { Kikwit, DRC, } 1995\end{array}$ & EBOV & $\begin{array}{l}\text {-RT-PCR days } 11-33 \text { (total } 18 \\
\text { specimens) + RT-PCR days } 22 \\
\text { and } 29 \text { (total } 2 \text { specimens, } \\
\text { same woman-RT-PCR days } \\
25 \text { and } 33 \text { ) }\end{array}$ & $\begin{array}{l}\text {-RT-PCR days } 11-33 \\
\text { (total } 20 \text { specimens) }\end{array}$ & NA & $\begin{array}{l}-\mathrm{RT} \text {-PCR days } \\
11-33 \text { (total } 19 \\
\text { specimen) }\end{array}$ \\
\hline $\begin{array}{l}4 \text { Patients, Gulu, } \\
\text { Uganda, } 2000\end{array}$ & SUDV & NA & -RT-PCR days $12-23$ & NA & $\begin{array}{l}-\mathrm{RT}-\mathrm{PCR} \text { days } \\
12-23\end{array}$ \\
\hline $\begin{array}{l}\text { Patient 1, Sierra Leone, } \\
2014\end{array}$ & EBOV & $\begin{array}{l}\text {-VI after day } 17 \text { (negative } \\
\text { blood test day } 17 \text { ) }\end{array}$ & $\begin{array}{l}\text {-VI after day } 17 \\
\text { (negative blood test day } \\
\text { 17) }\end{array}$ & $\begin{array}{l}-\mathrm{VI} \\
+\mathrm{RT}-\mathrm{PCR} \\
\text { until day } 40\end{array}$ & $\begin{array}{l}\text { + VI repeatedly } \\
\text { until day } 26 \\
+\mathrm{RT}-\mathrm{PCR} \text { until } \\
\text { day } 30\end{array}$ \\
\hline
\end{tabular}

NB days post-onset of symptoms.

EBOV, Ebola virus - Zaire; NA, not applicable; RT-PCR, reverse transcriptase PCR; SUDV, Ebola virus - Sudan; VI, virus isolation. 
extent, match the male latex condom. ${ }^{26}{ }^{27}$ As EBOV has a diameter of $80 \mathrm{~nm}$, the virus may be transmitted sexually by leaking through small pores in latex condoms. In vitro testing has been performed to examine the possibility of penetration of small viruses, by using test viruses and bacteriophages. ${ }^{28-31}$ These studies showed that, during tests mimicking real-life use, and when using a surrogate challenge virus of $27 \mathrm{~nm}$, a minority of condoms deemed intact may still leak through pores, risking passage of virus. The small size of the challenge virus allowed for conservative interpretations of condom efficacy. The study found that 12 of $470(2.6 \%)$ tested latex condoms leaked despite being intact in a regular water leakage test. They allowed virus penetration of an average $0.0007 \mathrm{~mL}$, which would correspond to about $0.00001 \mathrm{~mL}$ of semen in users, after correcting the value for viscosity and pressure. The worst performing condom did leak an estimated corrected value of some $0.05 \mathrm{~mL}$ semen. ${ }^{31}$ While condoms are interpreted as having a high enough efficacy as a barrier method against viral sexually transmitted disease (STD), for diseases where an infectious dose is present in $<0.1 \mathrm{~mL}$ of semen, pores in intact condoms may still be of relevance to transmission. ${ }^{29}$

The FDA approved female latex condom FC2 was tested for viral permeability in vitro by a similar bacteriophage as was used for male condom testing. The sample size was small, but found rates of pore leakage of $5 \%$ for the FC2, the same rate as the male latex condom. The pore leakage rate was deemed acceptable for providing adequate protection against viral STD (as opposed to the earlier polyurethane model FC1, which showed a higher frequency of pore leakage). ${ }^{26}$

\section{Male and female latex condom effectiveness}

No studies on condom effectiveness in relation to EBOV were identified. A Cochrane review examined the effectiveness of male condom use on HIV transmission in sero-discordant heterosexual couples, and estimated that HIV-negative partners were $80 \%$ less likely to become HIV infected than persons in similar relationships in which condoms were not used. ${ }^{32}$ Effectiveness rates for prevention of HIV are similar for female condoms. ${ }^{26} 3334$ The effectiveness of condoms in reducing transmission of HIV between discordant men who have sex with men is found to be lower, $61 \% .^{35}$

\section{Survival outside the host, implications to transmission}

In a laboratory study, dried EBOV did survive in the dark for several hours at $20-25^{\circ} \mathrm{C} .{ }^{36}$ EBOV can also survive in liquid media for more than 46 days in room temperature, which would be of relevance to condom handling and risk of infectious virus prevailing. ${ }^{37}$ This may be pertinent in view of oral sex and masturbation, as well as vaginal and anal sex. However, a recent study that confirms EBOV survives longer in liquids than in dried blood, also suggests that hospital conditions, as opposed to warmer and more humid conditions, seem to enhance survival outside the host. ${ }^{38}$ Hypothetically, climate conditions involving high humidity and high temperatures would hence not be promoting outsidehost survival. No studies were identified indicating transmission by way of a convalescent patient shedding virus outside the host and then causing transmission.

\section{DISCUSSION}

Viable Ebola virus can persist in semen for at least 82 days and may persist for much longer. Follow-up testing of the semen from this man was delayed until 700 days after symptom onset, at which time Ebola virus was not detected. EBOV RNA has been found in semen up to 284 days post-symptom onset, though it is not known if viable virus was present at that time. Viable EBOV has reportedly never been isolated from vaginal secretions, but EBOV RNA was detected on day 33 in the vaginal secretions of one of six women tested in the Kikwit epidemic. ${ }^{8}{ }^{9}$ Additionally, viable EBOV has been isolated in urine from one patient 26 days following his symptom onset and Ebola RNA from his sweat on day 40 after symptom onset. ${ }^{17}$ We identified one report of Ebola RNA in faeces on day 29, but no reports of viable virus in faeces. Following our review, findings presented from a woman infected with EBOV during the current epidemic and treated for her disease in Spain, support these outcomes. She had no detected EBOV in blood from day 19, but did have positive RT-PCR analyses in sweat until day 30 , in urine, conjunctival and vaginal swabs until day 28, and in saliva until day 22. Virus cultures were all negative. ${ }^{39}$

The existing evidence of viable Ebola virus in convalescent patients is weak. We found one published study reporting molecular evidence of sexual transmission of Ebola. Reports of suspect transmission support this finding. Still, the lack of published studies calls for cautious interpretations of transmission risks and epidemic impact. Field limitations, especially related to laboratory capacity, such as transport, and maintaining and handling the cold chain, have contributed to considerable challenges and may especially have influenced reported results in relation to virus isolation of Ebola. ${ }^{8} 9$

Stigma and discrimination associated with suspect cases of sexual transmission have been reported in those countries with high transmission and elsewhere. In Sierra Leone, the treatment of male Ebola survivors has included isolation and punitive measures. In India, a survivor from the current epidemic was isolated on arrival because of remaining Ebola RNA in his semen. ${ }^{23} 244041$ Ebola survivors need continued support including access to clinical care as well as to prevention, in order to mitigate any risks of exposing their intimate partners to remaining virus.

Despite conservative estimates of condom efficacy, it is difficult to assess the effectiveness of condoms in preventing sexual transmission of Ebola based on the available literature. EBOV has a reported high 
infectiousness, corresponding to as little as one organism causing disease, ${ }^{42}$ and hence small leakage volumes from condoms may be relevant. Additionally, there may be risks associated with used-condom handling, due to surviving virus in liquid media. Even if condoms are widely distributed to survivors for free, correct use on all occasions may be a challenge, and will require counselling efforts and monitoring of adherence. A study among youth in Monrovia, from 2011, suggests that, while condoms are distributed by community-based organisations and public health facilities, significant gaps yet exist, especially for youths, commercial sex workers and men who have sex with men. ${ }^{43}$ Transactional sex has been described as common, and associated with unprotected sex and with difficulties for women to negotiate safe sex. ${ }^{44}$ Behavioural change activities related to sexual health practices will need to be sensitive to gendered power imbalances found within, for example, transactional relationships.

\section{CONCLUSIONS}

On the basis of the evidence reviewed, we conclude that there is a risk of sexual transmission of Ebola from convalescent patients through sexual contact. The existing evidence indicates that there is a risk of viral persistence in semen, while the findings of viral RNA in vaginal secretions of one woman represent a weaker level of evidence. The recently reported case from Sierra Leone indicates that persistence of Ebola virus RNA in semen is possible up to 9 months after symptom onset. Similarly, molecular evidence suggests a verified case of sexual transmission of Ebola from Liberia. Studies are being implemented to evaluate the persistence of the virus in body fluids. In the meantime, testing semen of survivors after 3 months, and regularly until RT-PCR is negative twice, is recommended by the WHO. If this is not possible, abstinence, or else condom use, is recommended until at least 6 months post-symptom onset. All survivors are encouraged to practice safe sex. ${ }^{45}$

The evidence reviewed suggests that male and female latex condom use offers some protection against EBOV as compared to not using a condom. Efforts to promote adherence to behavioural change in line with recommendations need to be well grounded in the survivors' communities and will require targeted efforts.

Research is needed, including in-depth investigations of putative sexual transmission, to secure RT-PCR analyses, together with virus isolation and genetic sequencing, from all relevant body fluids. Combined efforts and international collaborations are needed to provide possibilities for advanced laboratory investigations. Additionally, in-depth analyses of the sexual history of cases during their incubation time should be carried out to evaluate level of exposure, as a complement to the regular field investigation of any exposure to acute cases. Cohort studies of Ebola survivors should urgently be implemented, in order to enable longitudinal analyses of viral persistence in all relevant body fluids, by RT-PCR, virus isolation and genetic sequencing. Any occurrence of secondary cases among sexual partners of survivors should be analysed in relation to sexual behaviour. A close collaboration with survivors' associations should be established in order to accurately design investigations on sensitive issues, as well as to mitigate any negative effects in an already vulnerable group.

This research is crucial to bring the current epidemic to an end, to inform epidemic preparedness, as well as to properly care for survivors and their communities.

Acknowledgements The authors would like to acknowledge James Kiarie, Marleen Temmerman, Rick Brennan and Bruce Aylward.

Contributors AT and NB planned and designed the review. AT performed the review of the literature, drafted the first version and handled revisions of the manuscript. AT, PF, CL and NB provided intellectual input to and revisions on the review. All the authors approved the final version.

Funding This research received no specific grant from any funding agency in the public, commercial or not-for-profit sectors.

Competing interests None declared.

Provenance and peer review Not commissioned; externally peer reviewed.

Data sharing statement No additional data are available.

Open Access This is an Open Access article distributed in accordance with the Creative Commons Attribution Non Commercial (CC BY-NC 4.0) license, which permits others to distribute, remix, adapt, build upon this work noncommercially, and license their derivative works on different terms, provided the original work is properly cited and the use is non-commercial. See: http:// creativecommons.org/licenses/by-nc/4.0/

\section{REFERENCES}

1. WHO. Situation report Ebola 2015. (cited 30 January 2015). http:// apps.who.int/ebola/ebola-situation-reports

2. To KK, Chan JF, Tsang AK, et al. Ebola virus disease: a highly fatal and panic-generating infectious disease reemerging in West Africa. Microbes Infect 2015; 17:84-97.

3. Osterholm MT, Moore KA, Kelley NS, et al. Transmission of Ebola viruses: what we know and what we do not know. MBio 2015;6: e01154.

4. Feldmann H, Geisbert TW. Ebola haemorrhagic fever. Lancet 2011;377:849-62.

5. Sonnenberg $P$, Field N. Sexual and mother-to-child transmission of Ebola virus in the postconvalescent period. Clin Infect Dis 2015;60:974-5.

6. Rogstad KE, Tunbridge A. Ebola virus as a sexually transmitted infection. Curr Opin Infect Dis 2015;28:83-5.

7. Mackay IM, Arden KE. Ebola virus in the semen of convalescent men. Lancet Infect Dis 2015;15:149-50.

8. Rodriguez LL, De Roo A, Guimard Y, et al. Persistence and genetic stability of Ebola virus during the outbreak in Kikwit, Democratic Republic of the Congo, 1995. J Infect Dis 1999;179(Suppl 1): S170-6.

9. Rowe AK, Bertolli J, Khan AS, et al. Clinical, virologic, and immunologic follow-up of convalescent Ebola hemorrhagic fever patients and their household contacts, Kikwit, Democratic Republic of the Congo. Commission de Lutte contre les Epidémies à Kikwit. $J$ Infect Dis 1999;179(Suppl 1):S28-35.

10. Saijo M, Niikura M, Ikegami T, et al. Laboratory diagnostic systems for Ebola and Marburg hemorrhagic fevers developed with recombinant proteins. Clin Vaccine Immunol 2006;13:444-51.

11. Richards GA, Murphy S, Jobson R, et al. Unexpected Ebola virus in a tertiary setting: clinical and epidemiologic aspects. Crit Care Med 2000;28:240-4.

12. Bausch DG, Towner JS, Dowell SF, et al. Assessment of the risk of Ebola virus transmission from bodily fluids and fomites. $J$ Infect Dis 2007;196(Suppl 2):S142-7.

13. Emond RT, Evans B, Bowen ET, et al. A case of Ebola virus infection. BMJ 1977;2:541-4. 
14. Christie A, Davies-Wayne GJ, Cordier-Lasalle T, et al., Centers for Disease Control and Prevention (CDC). Possible sexual transmission of Ebola virus - Liberia, 2015. MMWR Morb Mortal Wkly Rep 2015;64:479-81.

15. NYT. 2015. http://www.nytimes.com/2015/04/17/world/africa/ ebola-researchers-take-new-look-at-risk-of-sexual-transmission.html? mwrsm=Email\& $r=0$

16. Deen GF, Knust B, Broutet N, et al. Ebola RNA persistence in semen of Ebola virus disease survivors-preliminary report. $N$ Engl $J$ Med [epub ahead of print 14 Oct 2015].

17. Kreuels B, Wichmann D, Emmerich $\mathrm{P}$, et al. A case of severe Ebola virus infection complicated by gram-negative septicemia. $N$ Engl $J$ Med 2014;371:2394-401.

18. Formenty P, Leroy EM, Epelboin A, et al. Detection of Ebola virus in oral fluid specimens during outbreaks of Ebola virus hemorrhagic fever in the Republic of Congo. Clin Infect Dis 2006;42:1521-6.

19. Martini GA, Schmidt HA. [Spermatogenic transmission of the "Marburg virus." (Causes of "Marburg simian disease)"]. Klin Wochenschr 1968;46:398-400.

20. Dowell SF, Mukunu R, Ksiazek TG, et al. Transmission of Ebola hemorrhagic fever: a study of risk factors in family members, Kikwit, Democratic Republic of the Congo, 1995. Commission de Lutte contre les Epidémies à Kikwit. $J$ Infect Dis 1999;179(Suppl 1): S87-91.

21. Mate SE, Kugelman JR, Nyenswah TG, et al. Molecular evidence of sexual transmission of Ebola virus. $N$ Engl J Med 2015;373:2448-54

22. WHO. Internal report Visit to Island Clinic ETU, 28 November, 2014 2014.

23. WHO. Sexual transmission of Ebola in Sierra Leone. 2015

24. Africa A. 2015. (cited 24 January 2015). http://allafrica.com/stories/ 201501151813.html

25. WHO, UNFPA. Male latex condom: specification, prequalification and guidelines for procurement. 2010.

26. FDA. Female condom 2 FDA approval docuemnts and information. (8 December 2014). http://www.accessdata.fda.gov/cdrh_docs/pdf8/ P080002b.pdf

27. WHO, UNFPA. Scientific and technical requirements to formulate a female condom generic specification and prequalification scheme. 2012.

28. Carey RF, Herman WA, Retta SM, et al. Effectiveness of latex condoms as a barrier to human immunodeficiency virus-sized particles under conditions of simulated use. Sex Transm Dis 1992;19:230-4.

29. Carey RF, Lytle CD, Cyr WH. Implications of laboratory tests of condom integrity. Sex Transm Dis 1999;26:216-20.
30. Lytle C, Truscott W, Budacz A, et al. Important factors for testing barrier materials with surrogate viruses. Appl Environ Microbiol 1991;57:2549-54

31. Lytle C, Routson L, Seaborn G, et al. An in vitro evaluation of condoms as barriers to a small virus. Sex Transm Dis 1997;24:161-4.

32. Weller S, Davis K. Condom effectiveness in reducing heterosexual HIV transmission. Cochrane Database Syst Rev 2002;(1):CD003255.

33. Renzi C, Tabet SR, Stucky JA, et al. Safety and acceptability of the reality condom for anal sex among men who have sex with men. Aids 2003;17:727-31.

34. Eaton EF, Hoesley CJ. Barrier methods for human immunodeficiency virus prevention. Infect Dis Clin North Am 2014;28:585-99.

35. WHO. Prevention and treatment of HIV and other sexually transmitted infections among men who have sex with men and transgender people Recommendations for a public health approach. 2011.

36. Sagripanti J, Rom A, Holland L. Persistence in darkness of virulent alphaviruses, Ebola virus, and Lassa virus deposited on solid surfaces. Arch Virol 2010;155:2035-9.

37. Piercy T, Smither S, Steward J, et al. The survival of filoviruses in liquids, on solid substrates and in a dynamic aerosol. J Appl Microbiol 2010;109:1531-9.

38. Fischer R, Judson S, Miazgowicz K, et al. Ebola virus stability on surfaces and in fluids in simulated outbreak environments. Emerg Infect Dis 2015;21:1243-6.

39. Mora-Rillo M, Arsuaga M, Ramírez-Olivencia G, et al., La Paz-Carlos III University Hospital Isolation Unit. Acute respiratory distress syndrome after convalescent plasma use: treatment of a patient with Ebola virus disease contracted in Madrid, Spain. Lancet Respir Med 2015;3:554-62.

40. Reuters. Fear of Ebola's sexual transmission drives abstinence, panic: Reuters. 2015. http://www.reuters.com/article/2015/02/24/ us-health-ebola-sex-idUSKBNOLS24520150224

41. Devnani M, Guo Y. Ethical issues in isolating people treated for Ebola. BMJ 2015;350:h140.

42. Franz DR, Jahrling PB, Friedlander AM, et al. Clinical recognition and management of patients exposed to biological warfare agents. JAMA 1997:278:399-411.

43. Harris $\mathrm{AO}$, Jubwe $\mathrm{S}$, Kennedy $\mathrm{SB}$, et al. Condom social marketing program to prevent HIV/AIDS in post-conflict Liberia. Afr Health Sci 2011:11(Suppl 1):S77-81.

44. Atwood KA, Kennedy SB, Shamblen S, et al. Reducing sexual risk taking behaviors among adolescents who engage in transactional sex in post-conflict Liberia. Vulnerable Child Youth Stud 2012;7:55-65.

45. RHR, WHO. 2015. http://www.who.int/reproductivehealth/topics/rtis/ ebola-virus-semen/en/ 


\section{Correction}

Thorson A, Formenty P, Lofthouse C, et al. Systematic review of the literature on viral persistence and sexual transmission from recovered Ebola survivors: evidence and recommendations. BMJ Open 2016;6:e008859. A formatting error occurred in figure 1 of this paper. The information for patient $F$, which should be the green circle with 62 (referring to a negative test at 62 days) is superimposed on patient $\mathrm{E}$, ie one line higher than where it should be placed, on the line below for patient $\mathrm{F}$. The corrected figure is below.

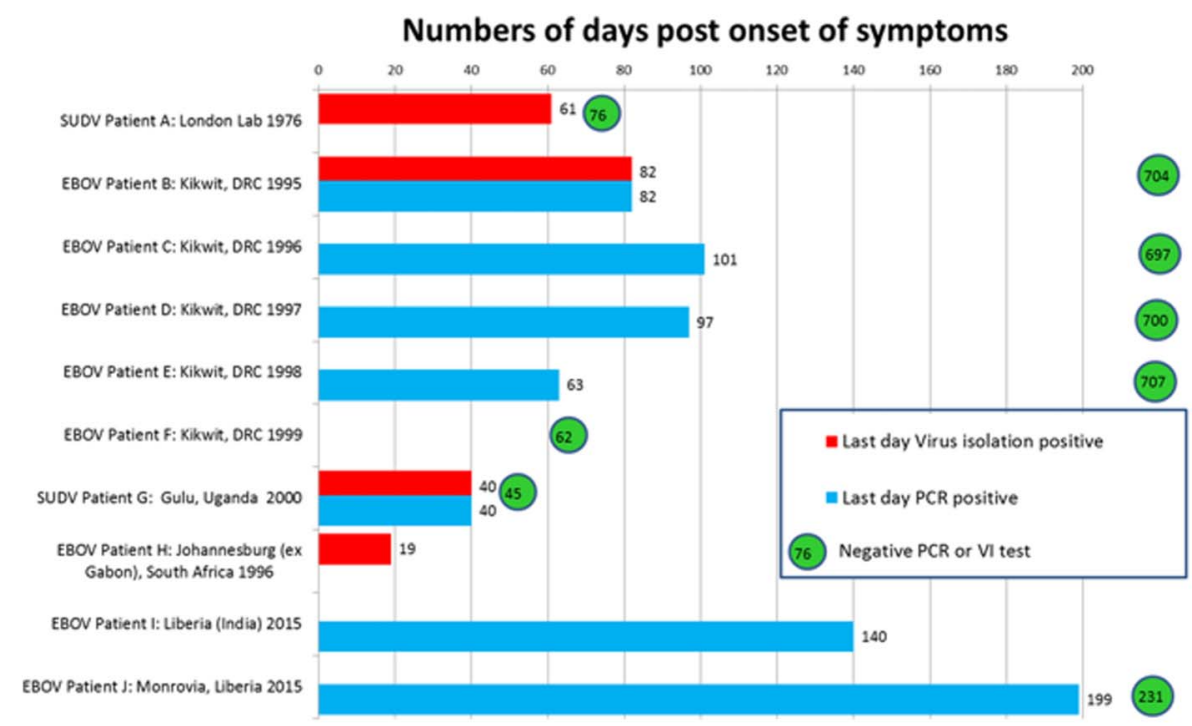

Figure 1

BMJ Open 2016;6:e008859corr1. doi:10.1136/bmjopen-2015-008859corr1

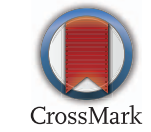

